\title{
STRATEGI PEMANDUAN TERPADU UNTUK MENCAPAI KESETIMBANGAN EKONOMI DAN KEAMANAN DI SELAT MALAKA DENGAN PENDEKATAN SSM
}

\author{
INTEGRATED PILOTING STRATEGY TOWARDS ECONOMIC AND SECURITY EQUILIBRIUM \\ USING SSM APPROACH
}

\author{
TSNB Hutabarat ${ }^{* 1}$, M. Syamsul Ma'arif*), Nimmi Zulbainarni "), dan Purnomo Yusgiantoro"*) \\ *) Sekolah Bisnis, IPB University \\ Jl. Raya Pajajaran, Bogor 16151 \\ **) Institut Teknologi Bandung \\ Jl. Ganesha No.10, Coblong, Kota Bandung, Jawa Barat 40132
}

\begin{abstract}
One of the main issues facing the Government in Malacca Strait is the security and safety issue, which threatens the users of sea transportation service and potentially interferes with the business operation. In fact, most of the international distribution lines pass through the Malacca Strait, making it the busiest strait in the world. On the other hand, the high cost of maintaining security and safety in the area burdens the government. Hence, this research aims to develop a strategy in handling the sea transportation system to achieve the equilibrium between economic efficiency and the government's effectiveness in maintaining the security and safety of the shipping traffic in Malacca Strait. This study is a problem solving-based research using Soft System Methodology. As a result, the integrated piloting strategy has been developed as a recommendation to be implemented. With this strategy, the ships that pass through the Malacca Strait are advised to adopt integrated piloting. The pilots and the security guards would be on board and safely and securely help the ship pass through the Malacca Strait. By that, safety and security would be guaranteed, and the business objectives would be achieved.
\end{abstract}

Keywords: malacca strait, maritime study, sea transportation, soft system methodology

\begin{abstract}
Abstrak: Salah satu tantangan terbesar yang dihadapi pemerintah di Selat Malaka adalah permasalahan keamanan dan keselamatan yang mengancam para pengguna moda transportasi laut sehingga berpotensi mengganggu kelancaran operasional bagi para pelaku bisnis. Padahal sebagian besar alur distribusi internasional melewati Selat Malaka, menjadikan selat ini sebagai selat tersibuk di dunia. Mengingat pentingnya peran Selat Malaka maka keamanan maritim menjadi prasyarat bagi keberlangsungan aktivitas ekonomi. Di sisi lain upaya menjaga keamanan serta keselamatan di wilayah tersebut membebani pemerintah dengan biaya yang sangat besar. Berdasarkan latar belakang tersebut penelitian ini bertujuan untuk merumuskan strategi di dalam menangani sistem transportasi laut agar terjadi kesetimbangan antara efisiensi ekonomi bagi pelaku bisnis, serta efektivitas instansi pemerintah dalam menjaga keamanan dan keselamatan pelayaran di Selat Malaka. Studi ini merupakan penelitian berbasis problem solving menggunakan metode SSM (Soft System Methodology). Sebagai hasil dari penelitian ini disusun rekomendasi berupa Strategi Pemanduan Terpadu di mana kapal-kapal yang melintasi Selat Malaka disarankan untuk menggunakan Pemanduan Terpadu yaitu petugas Pandu yang terintegrasi dengan keberadaan petugas keamanan yang turut on board di kapal selama melintas di Selat Malaka, dengan segala tantangannya, sehingga keamanan dan keselamatan terjamin, keuntungan bisnis tercapai serta terwujud efisiensi ekonomi bagi semua pihak yang terlibat.
\end{abstract}

Kata kunci: selat malaka, studi kelautan, transportasi laut, soft system methodology,

\footnotetext{
${ }^{1}$ Corresponding author:

Email: hutabarat35@yahoo.com
} 


\section{PENDAHULUAN}

Transportasi merupakan suatu usaha dan kegiatan pengangkutan atau pemindahan barang atau jasa dari suatu tempat ke tempat lain. Menurut Gunawan (2014), terdapat lima unsur pokok yang harus diperhatikan dalam sistem transportasi, yakni orang atau barang, kendaraan sebagai alat angkut, jalan sebagai prasarana angkut, terminal, dan organisasi sebagai pengelola angkutan. Jalan (the way) menjadi salah satu unsur utama yang perlu diperhatikan dalam transportasi karena menjadi basis bagi alat angkut untuk bergerak, baik melalui darat, udara maupun melalui laut.

Menurut Dong (2015), meskipun moda transportasi udara telah menjadi transportasi yang memasyarakat, namun jalur laut masih menjadi primadona dalam dunia bisnis. Hal ini dikarenakan daya angkut (kapasitas) yang tinggi dan biaya yang lebih kompetitif dibandingkan dengan moda transportasi lainnya. Selain itu biaya moda transportasi laut yang relatif murah dibandingkan transportasi lainnya menjadikan tranportasi laut sebagai 'central integrated component' dalam sistem logistik yang mencakup berbagai macam jenis bisnis, mulai dari korporasi berskala besar hingga usaha kecil pada toko di pinggir jalan (Eon, 2012). Hal ini menjadi salah satu alasan dasar dalam keberlangsungan pengunaan moda transportasi laut untuk terus berlanjut dalam upaya meningkatkan perkembangan bisnis dan perekonomian dunia.

Castonguay (2018) mengungkapkan bahwa saat ini distribusi barang di dunia dengan menggunakan transportasi laut mencapai $90 \%$. Kondisi ini dapat dipahami dikarenakan secara geografis $70 \%$ permukaan bumi berupa lautan (Nunez, 2019). Halpern (2018) menambahkan bahwa pengangkutan barang melalui laut sebagian besar melewati Samudera Atlantik dan Lingkar Samudera Pasifik, dengan Jalur perdagangan utama yang digunakan adalah "Pilar Hercules", yaitu lintasan Mediterania dan Terusan Suez ke Samudera Hindia yang melalui Selat Malaka.

Banyaknya kegiatan bisnis yang memanfaatkan jalur pelayaran Selat Malaka menumbuhkan perhatian pelaku usaha untuk mendapat jaminan keamanan dan keselamatan. Para pengguna jasa angkutan laut, baik perusahaan pelayaran maupun para pelaut, sangat berharap agar negara pantai di Selat Malaka dapat bekerja sama dengan baik untuk menjamin keamanan bagi pelaku bisnis maupun para pengguna jasa angkutan laut. Adapun yang dimaksud dengan negara pantai di Selat Malaka adalah Indonesia dan Malaysia.

Kegiatan dalam rangka menjaga keamanan dan keselamatan pelayaran di Selat Malaka memerlukan biaya yang relatif sangat besar. Bagi negara yang belum tergolong sebagai negara maju, penggunaan dana untuk kegiatan operasional ini dirasakan cukup memberatkan beban anggaran negara, sehingga mengemuka dikotomi berupa "Gun or Butter", yaitu model klasik dari kurva kemungkinan produksi dengan menggunakan hubungan antara "senjata" (anggaran militer atau keamanan) dan "mentega" (kebutuhan pangan atau ekonomi dan bisnis). Istilah tersebut menunjukkan bahwa dalam penggunaan anggaran suatu negara, bila terjadi peningkatan di satu bagian akan berdampak kepada penurunan bagian lainnya (Crawford, 1990). Namun, menurut Dombrowski (2005), apabila pemerintah mampu menangani dengan baik, maka dikotomi tersebut akan berubah menjadi kontinum Gun and Butter, yakni keamanan yang tetap terjamin dengan tidak menomorduakan pertumbuhan ekonomi atau perkembangan bisnis. Menurut Hanoch (1975), di dalam melaksanakan bisnis, agar distribusi dapat berjalan dengan baik, maka keamanan perlu dijamin. Efisiensi tidak akan tercapai apabila keamanan tidak terjamin.

Pentingnya aspek keamanan di dalam operasional bisnis telah dibahas di dalam beberapa studi sebelumnya. Burns (2013) menjelaskan bahwa pasca peristiwa 9/11, dunia mengalami kecemasan terhadap ancaman keamanan. Di dalam kemaritiman, penerapan ISPS code (International Ship and Port Security) adalah salah satu langkah paling menjanjikan dan efektif untuk mengurangi ancaman keamanan, baik dalam hal serangan teroris, perompakan maupun pembajakan laut. Implementasi langkah-langkah ini membutuhkan investasi dalam jumlah besar dalam bentuk pembelian, pemeliharaan, dan amortisasi peralatan modal baik di pelabuhan maupun di kapal. Pada penelitian ini Burns (2013) mengevaluasi tingginya jumlah anggaran yang dialokasikan oleh pemerintah, pemilik kapal dan otoritas pelabuhan, yang mana kemudian ditemukan bahwa potensi ancaman keamanan maritim baik secara langsung maupun tidak langsung adalah sangat dinamis. Sedemikian besarnya ancaman tersebut hingga melebihi dari nilai bisnis itu sendiri. Pertumbuhan ekonomi atau bisnis akan secara proporsional meningkatkan kerentanan rantai pasokan atau ekonomi nasional sebagai target keamanan. 
Pada penelitian Burns (2016) juga membuktikan pentingnya faktor keamanan dalam penyelenggaraan transportasi, mengingat transportasi merupakan sepertiga dari keseluruhan aktivitas logistik. Seluruh rantai pasokan sangat bergantung pada transportasi, dari ekstraksi bahan baku, ke produksi, pergudangan, hingga distribusi ke konsumen akhir. Untuk itu transportasi yang efisien dapat menambah nilai pada produk dengan memastikan keselamatan, keamanan, dan kecepatan pengiriman yang optimal tanpa mengurangi kualitas atau kuantitas produk. Oleh karena itu, keamanan adalah prasyarat penting dari operasi transportasi modern.

Dalam konteks regulasi atau pengaturan bagi pengguna jasa angkutan laut di Selat Malaka, sebagai Selat yang digunakan untuk pelayaran Internasional, mengacu pada studi kasus Selat Torres, maka pemanduan dalam perairan internal adalah hal yang dapat diterima dan diterapkan oleh negara pantai secara unilateral (Roberts et al. 2005), sehingga sangat beralasan jika Pemerintah Indonesia menerapkan wajib pandu bagi pengguna jasa angkutan laut di Selat Malaka. Mengingat sejauh initelah terbukti bahwa faktor manusia merupakan penyebab utama terjadinya kecelakaan di laut (Bateman, 2010), maka keberadaan Pandu diharapkan akan mengurangi terjadinya kecelakaan di Selat Malaka, mengingat para Pandu relatif lebih menguasai situasi medan.

Masih terkait biaya keamanan, Khalid (2006) melalui penelitiannya membahas tentang pemilihan antara biaya keamanan yang harus dikeluarkan untuk mengamankan logistik di pelabuhan dan keuntungan yang diperoleh dari keamanan tersebut. Penelitian ini membuktikan bahwa semakin banyak sistem keamanan yang diterapkan akan menimbulkan konsekuensi kepada kecepatan distribusi dan efisiensi. Untuk itu melakukan kesetimbangan antara keduanya merupakan suatu keharusan.

Namun demikian, pembiayaan sektor keamanan untuk pemenuhan rasa aman bagi semua warga negara perlu dilakukan sehemat mungkin, agar tujuan keamanan negara dan tujuan bernegara lainnya dapat tercapai secara proporsional. Pemilihan antara keamanan dan ekonomi tentu akan memiliki dampak masingmasing. Dalam konteks transportasi laut, mengabaikan keamanan dan keselamatan pelayaran demi mendapatkan keuntungan ekonomi akan menimbulkan permasalahan baru yang tak kalah besarnya yang justru akan mengakibatkan kerugian ekonomi yang besar bagi perusahaan. Untuk itu perlu dicapai suatu kondisi kesetimbangan antara keuntungan ekonomi dan biaya keamanan. Kesetimbangan yang dimaksud dalam penelitian ini adalah, kondisi di mana keamanan akan mendukung adanya peningkatan keuntungan, namun biaya keamanan tidak lebih tinggi dibanding peningkatan keuntungan.

Sebagaimana yang diungkapkan oleh Button dan Thibault (2005) bahwa terdapat hubungan antara biaya yang dikeluarkan untuk peningkatan keamanan dengan keamanan yang diperoleh serta peningkatan keuntungan (benefit), mereka juga menyatakan bahwa kepentingan pelaku ekonomi dalam melakukan efisiensi akan saling berpengaruh terhadap keamanan. Untuk itu, agar pelaku ekonomi dapat meningkatkan keuntungan dengan biaya pengamanan yang relatif tidak tinggi, maka terdapat peranan seharusnya dapat dipenuhi oleh pelaku kebijakan, dalam hal ini pemerintah.

Dengan penerapan pemanduan terpadu, diharapkan akan dapat mengisi kekosongan sektor patroli, mengefektifkan operasional keamanan dan mengefisienkan biaya patroli keamanan di Selat Malaka. Di samping itu, menambah pendapatan negara dari Piloting charge serta memberi peluang untuk terciptanya lapangan kerja baru. Hal ini dikarenakan pemanduan terpadu berfokus pada pengadaan sumber daya manusia bukan pengadaan material sehingga biaya yang dikeluarkan relatif lebih murah dibandingkan dengan penambahan kapal atau senjata. Lebih dari itu, Pemanduan Terpadu ini akan mengurangi jumlah alokasi pengunaan Kapal patroli di Selat Malaka sehingga kapal patroli keamanan di laut dapat digunakan untuk patroli di sektor patroli lainnya.

Pemanduan terpadu ini juga merupakan win-win solution terhadap penolakan akan adanya Maritime Private Security yang saat ini dianggap menggangu kepentingan negara pantai (Buerger, 2014), karena adanya permasalahan hukum terhadap keberadaan senjata di atas kapal dagang, seperti: negara mana yang memiliki kewenangan atas pengunaan senjata, rezim hukum negara mana yang akan diterapkan untuk penggunaan kekuatan mematikan, bagaimanakah bila negara bendera kapal dan negara pantai berbeda pendapat dalam hal intepretasi terhadap hukum dan penggunaan kekuatan senjata mematikan tersebut (Tempest, 2012). 
Berdasarkan latar belakang tersebut di atas, penelitian ini bertujuan untuk merumuskan strategi yang tepat dalam menangani sistem transportasi laut agar terjadi kesetimbangan antara efisiensi, bagi pelaku bisnis, dan efektivitas bagi instansi pemerintah dalam menjaga keamanan dan keselamatan pelayaran di Selat Malaka. Kebaruan yang ditawarkan oleh penelitian ini adalah dihasilkannya suatu strategi baru yang memungkinkan terwujudnya keseimbangan antara efisiensi bagi pelaku bisnis, terjaganya keselamatan dan keamanan pengguna jasa angkutan laut serta tercapainya efektivitas operasional bagi penegak hukum di laut. Terlebih dari pada itu, diharapkan akan menambah pendapatan pemerintah dari pilot fare serta terciptanya lapangan kerja baru.

\section{METODE PENELITIAN}

Penelitian ini dilakukan melibatkan para pakar/ key person yang terkait langsung dan benar-benar memahami permasalahan yang terjadi di Selat Malaka sebanyak 12 orang yang mewakili penegak hukum, petugas Pelabuhan, pelaut/kepanduan, pelaku ekonomi dan pakar maritim baik dari instansi pemerintah maupun pelaku bisnis. Adapun waktu penelitian dilaksanakan pada bulan Februari 2019. Pengambilan data dalam penelitian ini diawali dengan studi literatur baik mempelajari teori pendukung maupun menjadikan penelitian terdahulu sebagai lesson learned dan melakukan wawancara kepada para ahli serta melakasanakan Focus Group Discussion (FGD) yang dilaksanakan pada 2 Februari 2019 di Batam dengan menghadirkan pakar dan pelaku di lapangan baik di bidang keselamatan mapun keamanan di laut. Hal ini dilakukan sesuai dengan tujuan pertama penelitian adalah menganalisis situasi keamanan dan mengetahui akar permasalahan yang terjadi di Selat Malaka, untuk itu peneliti menyebar kuisoner di delapan pelabuhan di sepanjang Selat Malaka; Aceh, Belawan, Tanjung Balai Asahan, Dumai, Tanjung Balai Karimun, Batam, Tanjung Uban dan Tanjung Pinang. Dari 400 kuisoner yang disebarkan hanya 298 kuisoner yang diterima kembali dan valid untuk dapat digunakan sebagai bahan penelitian. Berdasarkan hasil FGD tersebut dan 298 kuesioner berhasil dikumpulkan serta gambaran kondisi existing permasalahan di Selat Malaka, maka disusunlah rich picture. Tahap kedua adalah merancang model konseptual yang dapat diimplementasikan dalam mengangani permasalahan di Selat Malaka. Pada tahap ini peneliti menggunakan metode SSM.
Memformulasikan strategi dalam rangka mewujudkan kesetimbangan antara efisiensi ekonomi dan efektifitas keamanan untuk mengatasi permasalahan di Selat Malaka merupakan kegiatan yang bersentuhan dengan banyak pemangku kepentingan, baik instansi sipil maupun keamanan dan militer, dalam maupun luar negeri, sehingga kondisi yang dihadapi adalah kompleks, berkelanjutan, rumit dan tidak terstruktur. Hal ini merupakan karakteristik dari SSM (Soft System Methodology) (Khisty, 1995). Dengan alasan tersebut maka penelitian ini menerapkan pendekatan SSM.

Pendekatan metodologi SSM merupakan pendekatan riset melalui tindakan yang dipandang sebagai upaya untuk memperoleh pengetahuan berdasarkan pengalaman (experience based knowledge), sehingga Uchiyama (2009) menyebutkan bahwa SSM merupakan bagian dari riset tindakan (action research).

Proses SSM meliputi tujuh tahap yang merupakan suatu siklus yang dimulai dengan penemuan problematical situation sampai dengan penentuan saran/tindakan untuk melakukan penyempurnaan atas problematical situation. (Checkland dan Scholes, 1990; Checkland dan Poulter, 2006; Hardjosoekarto, 2013). Ketujuh langkah tersebut meliputi:

Pada tahap pertama menemukan situasi problematik dan tidak terstruktur (the problem situation considered problematic and unstructured). Pada tahap pertama, peneliti mengeksplorasi masalah atas situasi dunia nyata yang dihadapi. Peneliti mengumpulkan sejumlah informasi awal tentang problematika yang terjadi dalam situasi keamanan dan permasalahan ekonomi yang ada di Selat Malaka. Selanjutnya berusaha menggali asumsi-asumsi dan perspektif yang ada. Tujuannya untuk menjadi pertimbangan atas sisi kelemahan dan kelebihan sebagai bahan ekplorasi dari solusi efektif pada strategi penyetimbang antara efisiensi ekonomi dan efektivitas keamanan.

Tahap kedua menggambarkan situasi permasalahan (problem situation expressed). Situasi permasalahan problematik pada dunia nyata diungkapkan dengan menggunakan rich picture, yang menggambarkan bagaimana dinamika yang terjadi pada pemangku kepentingan dalam menangani kasus-kasus gangguan keamanan di Selat Malaka maupun bagaimana pemanfaatan ekonomi di sepanjang Selat Malaka. 
Tahap ketiga, menentukan root definition dari sistem yang terkait (root definition of relevant purposeful activity systems). Root definition merupakan pandangan ideal dari sistem yang seharusnya berjalan. Tujuan root definition adalah untuk menggambarkan apa yang harus dilakukan (what), mengapa harus dilakukan (why), bagaimana melakukannya (how), melalui cara pandang (worldview) tertentu terhadap situasi permasalahan (Hadjosoekarto, 2012). Agar root definition yang disusun dapat digunakan dalam membuat model konseptual, maka root definition disempurnakan dan dibantu dengan analisis CATWOE (Customer, Actors, Transformation, Worldview, Owners dan Environmental Constraints) (Hardjosoekarto, 2013).

Tahap keempat, menyusun model konseptual (ConseptualModels). Model konseptual dibuatmengacu kepada root definition dan menjadi pembanding antara situasi dunia nyata dengan problematic situation yang sedang dikaji, yang telah distrukturkan pada tahap dua sehingga didapat berbagai pandangan guna memperoleh saran tindak dalam rangka memperbaiki situasi dunia nyata yang dianggap problematic (Hadjosoekarto, 2012).

Tahap kelima, membandingkan model konseptual dengan dunia nyata (comparison of conceptual models and real world). Pada langkah ini yang dilakukan adalah membandingkan tahap 2 dan tahap 4. Pembandingan pada tahap ini dilakukan melalui berbagai pertanyaan yang berkaitan dengan kehadiran elemen model konseptual dunia nyata, menggunakan matriks atau tabel yang bisa didapatkan di antaranya dengan cara diskusi (Hardjosoekarto, 2013).

Tahap keenam, menentukan perubahan yang memungkinkan, sesuai dengan yang diharapkan (feasible and desirable change). Setelah melakukan diskusi dan penelitian untuk membandingkan model konseptual dan perceived reality, langkah berikutnya merumuskan rekomendasi perubahan yang diperlukan untuk menangani permasalahan yang ada. Menurut Checkland dan Poulter (2006), terdapat tiga aspek dalam melakukan perbaikan, penyempurnaan atau perubahan, yaitu perubahan yang terkait dengan struktur, perubahan yang berkaitan dengan proses, dan perubahan yang berkaitan dengan sikap.

Tahap ketujuh, tindakan perbaikan (action to improve the problem situation). Pada langkah ini, para pihak yang berkepentingan dalam kondisi telah menerima perubahan yang diinginkan. Hal ini yang akan menjadi tanda bahwa siklus SSM telah lengkap dan selesai atau dengan kata lain pengambilan langkah berikutnya terpulang kembali kepada organisasi tersebut.

Pengumpulan data untuk metode SSM dilakukan melalui wawancara, diskusi secara mendalam dan FGD (Focus Group Discussion) dengan pakar internal dan para tokoh kunci yang banyak terlibat langsung terhadap kesetimbangan ekonomi dan keamanan di Selat Malaka, terutama Bakamla RI dan TNI AL serta pemangku kepentingan yang terlibat. Hal ini dikarenakan para pakar maupun tokoh kunci harus betulbetul faham dengan kondisi yang sebenarnya dan betulbetul mengetahui situasi yang menjadi problematika sehingga dapat menjelaskan keadaan dan kondisi yang sebenarnya yang perlu dicarikan solusinya.

\section{HASIL}

Pada bagian ini dibahas pendekatan SSM yang diterapkan untuk merumuskan strategi pemanduan terpadu dalam rangka mewujudkan kesetimbangan antara efisiensi bagi pelaku bisnis serta efektivitas keamanan yang diselenggarakan oleh pemerintah.

\section{Tahap pertama - Menemukan situasi problematik dan tidak terstruktur (Situation Considered Problematic/Unstructured Situation)}

\section{Gambaran umum Selat Malaka}

Agar dapat memberikan pandangan dari berbagai perspektif, berbagai sumber data dimanfaatkan di dalam studi ini sehingga dapat menggambarkan rich picture. Gambaran kondisi Selat Malaka dapat dimulai dari kondisi geografis. Berdasarkan The International Hydrographic Organization (IHO) yang disebut Selat Malaka adalah bentangan selat dari ujung barat Sumatera hingga Tanjung Balai Karimun (IHO, 2013). Mengacu pada ketentuan tersebut, maka secara geografis negara pantai pada Selat Malaka adalah Indonesia dan Malaysia. Akan tetapi mengingat kelanjutan dari Selat Malaka adalah Selat Singapura yang merupakan tujuan persinggahan mayoritas kapal yang melintas selat Malaka, maka penelitian ini juga menjadikan Selat Singapura sebagai bagian dari penelitian. 
Selat Malaka merupakan selat tersibuk di dunia karena selat ini merupakan Sea Lines of Communication (SLOC) dan jalur pelayaran bagi kapal-kapal tanker dunia atau Sea Lines of Oil Trade (SLOT). Terdapat sekitar 100.000 kapal per hari atau hampir 50\% kapal perdagangan dunia yang melintas di selat ini, termasuk 16 Juta barrel minyak per hari yang setara dengan sepertiga minyak dunia atau $70 \%$ minyak di Asia melintas di Selat Malaka (Heng, 2017). Adapun nilai bisnis yang diperoleh dapat mencapai USD \$ 435 Milyar (Kemenkomar, 2018). Secara geografis, 75\% dari perairan di Selat Malaka adalah laut teritorial Indonesia dan hanya 25\% yang merupakan perairan teritorial Malaysia dan Singapura (Jusuf, 2016).

\section{Situasi Keamanan dan Keselamatan di Selat Malaka}

Dari segi maritim, Selat Malaka memiliki kerawanan karena pada selat ini terdapat alur pelayaran SLOC dan SLOT tersempit di dunia, yaitu 1.5 Mil Laut, dan terdapat kedangkalan sekitar 25 meter. Di Selat Malaka tidak kurang dari 60 kecelakaan tabrakan kapal terjadi setiap tahunnya (Calamur, 2017). Selain kejadian kapal tabrakan dan kandas, kecelakaan pelayaran lainnya yang sangat mungkin terjadi, seperti kebakaran dan karam.

Selain bahaya kecelakaan navigasi, di Selat Malaka juga rawan terjadi perompakan (Armed Sea Robery), yaitu pencurian atau pembegalan yang dilakukan pada kapal yang berlayar melintasi Selat Malaka. Di samping kerawanan terhadap keamanan dan keselamatan yang dapat merugikan pelaku bisnis, terdapat banyak kerawanan lainnya yang merugikan negara seperti penyeludupan, imigran gelap dan kejahatan lintas negara. Selat Malaka yang dijuluki sebagai The Most Dangerous Water in the World (Fargo, 2004), menjadi area yang dikhawatirkan keamanannya oleh para pelaku ekonomi karena tingginya angka perompakan.

Beragam upaya dilakukan oleh Pemerintah Indonesia dalam menjaga keamanan, mulai dari pemanfaatan sensor berupa Monitoring Radar di sepanjang Selat Malaka, patroli individual oleh TNI AL, patroli antar instansi Pemerintahan Indonesia, hingga Patroli Terkoordinasi (Patkor), yaitu bentuk kerjasama patroli yang dilaksanakan secara bersamaan antar instansi dari negara tetangga dengan sektor patroli di wilayah masing-masing. Selain itu terdapat juga inisiatif yang dilakukan secara gabungan oleh Indonesia, Malaysia,
Singapura, dan Thailand dalam melakukan pemantauan dan patroli negara yang disebut Malacca Straits Patrol (MSP) yang terdiri dari Malacca Strait Sea Patrol (MSSP), Eyes in the Sky (EiS) dan Intelligence Exchange Group (IEG).

Padakegiatan MSPini, masing-masing negaradiharuskan untuk melakukan patroli laut, dikombinasikan dengan patroli udara maritim di mana di kedua jenis kegiatan patroli tersebut juga memanfaatkan informasi intelijen yang relatif akurat karena sudah merupakan pertukaran informasi intelijen keempat negara peserta.

\section{Pemanduan dan Wajib Pandu}

Pandu (Maritime Pilot) adalah pelaut yang memiliki keahlian di bidang nautika dan diberi kewenangan oleh pemerintah, yang berkemampuan untuk memberi saran dan informasi demi keselamatan bernavigasi di suatu perairan. Hal ini disebabkan karena Pandu tersebut lebih mengenal pantai, kedangkalan, pelabuhan, dermaga, cuaca, arus, pasang surut, aturan kepelautan, batasan dan larangan tertentu di perairan tersebut (Pelindo, 2017).

Dalam sistem transportasi laut internasional dikenal Pandu Wajib (Compulsory Piloting) dan Pandu Sukarela (Voluntary Piloting). Pandu wajib adalah kepanduan yang dilaksanakan di dalam area pelabuhan, mengingat kepadatan aktivitas lalu lintas laut di area pelabuhan yang akan sangat membahayakan bila kapal lepas dan sandar di pelabuhan tanpa adanya bantuan Pandu. Adapun kepanduan sukarela dilaksanakan pada alur yang secara kondisi hidrografi cenderung akan membahayakan kapal, sehingga para Nahkoda atau Kapten kapal, walau tidak menjadi keharusan, dapat meminta bantuan pemanduan (PP no. 5, 2010). Apabila dilihat dari kepadatan lalu lintas, bahaya navigasi dan kerawanan lainnya, pemberlakuan Wajib Pandu di Selat Malaka seharusnya sudah menjadi kebutuhan mendesak.

\section{Lembaga-lembaga yang menangani sektor maritim.}

Di Indonesia terdapat 13 lembaga yang memiliki kewenangan untuk penyidikan di laut dengan kewenangan dan dasar hukum masing-masing. Hal ini mengakibatkan sulitnya koordinasi antar lembaga dalam mengamankan wilayah laut dan yurisdiksi Indonesia, termasuk di Selat Malaka. Dari ketiga belas lembaga terdapat enam instansi yang memiliki kapal patroli 
dan melaksanakan penegakan hukum di laut yaitu: TNI AL, Bakamla, Polisi perairan, Bea dan Cukai, Ditjen Perhubungan Laut (KPLP) dan Kementerian Kelautan dan Perikanan (KKP).

Bagi Indonesia sendiri, dibutuhkan investasi yang besar dalam rangka mewujudkan proses pengawasan yang memadai, termasuk Alutsista, sistem pemantauan dan personel yang memiliki kapabilitas untuk meningkatkan terwujudnya kemanan laut di Selat Malaka. Untuk itu diperlukan suatu strategi yang dapat mengoptimalkan Alutsista serta jumlah personel yang ada saat ini dengan tetap menghasilkan kualitas keamanan dan keselamatan yang maksimal di Selat Malaka.

\section{Tahap kedua-Menggambarkan Situasi Permasalahan (Problem Situation Expressed)}

Dari penjelasan yang dijabarkan pada tahap pertama, dapat digambarkan rich picture dari kondisi Selat Malaka seperti tergambar pada Gambar 1.

\section{Tahap ketiga - Menentukan Root Definition dari Sistem Terkait (Root Definitions of Relevant System)}

Pada tahap ini dibuat root definition berdasarkan rich picture di tahap kedua. Root definition dari studi ini dapat digambarkan sebagai berikut: $\boldsymbol{P}$ (What) Suatu sistem atau strategi; $\boldsymbol{Q}$ (How) dengan menempatkan Pandu serta petugas keamanan laut di atas kapal dan meningkatkan koordinasi antar instansi terkait serta pelaku bisnis; $\boldsymbol{R}$ (Why) untuk mengatasi permasalahan transportasi laut di perairan Selat Malaka dalam rangka mewujudkan kesetimbangan antara efisiensi ekonomi atau bisnis dan efektivitas keamanan. Langkah selanjutnya adalah mendefinisikan CATWOE sebagai berikut: C (Customer - Pengguna jasa transportasi laut yang melalui perairan Selat Malaka); A (Actors - Pelaut, Pandu, Penegak hukum (Bakamla, TNI AL), Pelaku Bisnis (Perusahaan Pelayaran, produsen, pengusaha ekspor/impor)); $\mathrm{T}$ (Transformation - Perubahan dari situasi kurang terintegrasinya sistem penyelamatan dan pengamanan sehingga menjadi sinergi, bukan saja internal para actors melainkan antara actors dan customers); W (Worldview - Penerapan Strategi Pemanduan Terpadu pada jalur lalu lintas transportasi laut tersibuk di dunia dengan menggunakan kriteria Suitability (kesesuaian), Feasibility (kelayakan), Acceptability (penerimaan), Distinguishability (dapat dibedakan), Completeness (kelengkapan)); O (Owner - Pemerintah Indonesia); E (Environmental Constraints - Konflik kepentingan, keterbatasan anggaran dan perbedaan kepentingan).

\section{Tahap keempat - Menyusun Model Konseptual (Building Conceptual Model)}

Pada tahap ini dibuat model konseptual yang secara umum dapat digambarkan sesuai Gambar 2. Model konseptual ini merupakan penggambaran dari hubungan antara kepentingan atau target dan peran dari masingmasing pihak yang terlibat serta faktor-faktor yang mempengaruhi dan kendala-kendala yang dihadapi di dalam penyelenggaraan transportasi laut di Selat Malaka. Masing - masing pihak memiliki peran yang saling terkait dan melengkapi.

Tahap kelima - Membandingkan Model Konseptual dengan Dunia Nyata (Comparison of Conceptual Model and Real World)

Model konseptual di dalam studi ini dibandingkan dengan kondisi di lapangan melalui diskusi dan wawancara mendalam dengan para pihak terkait, baik pengguna jasa angkutan, para pelaut dan instansi yang bertanggung jawab kepada keselamatan dan keamanan di laut, termasuk pelaku di lapangan maupun pejabat pembuat keputusan. Terdapat 298 narasumber yang diwawancarai, yang terdiri atas 166 pelaut, 30 pengguna jasa laut, serta 102 petugas keamanan dan pelabuhan. Para pelaut dan petugas pelabuhan yang diwawancara adalah pelaut dari kapal dengan tujuan ke pelabuhan besar Indonesia di sepanjang Selat Malaka yaitu Pelabuhan Lhokseumawe, Pelabuhan Belawan, Pelabuhan Dumai dan Pelabuhan Batam, serta PT. Pelindo I sebagai badan pemerintah yang bertanggung jawab dalam jasa pelabuhan di sepanjang Selat Malaka.

Dari hasil perbandingan antara model konseptual dengan dunia nyata, diperoleh hasil dari 298 responden terdapat $179(60 \%)$ responden yang menyatakan sangat setuju dan $89(30 \%)$ responden yang setuju dengan diterapkannya Strategi Pemanduan Terpadu di Selat Malaka. Mereka beranggapan bahwa Strategi Pemanduan Terpadu sesuai dengan kenyataan di lapangan dan merupakan solusi yang tepat untuk mengatasi permasalahan yang mereka hadapi di perairan Selat Malaka. Adapun 30 orang responden $(10 \%)$ menyatakan tidak setuju karena mereka belum yakin mengenai mekanisme pelaksanaan Pemanduan Terpadu tersebut serta hal-hal lain yang disebabkan oleh belum jelasnya pemahaman responden tentang Strategi Pemanduan Terpadu ini. 


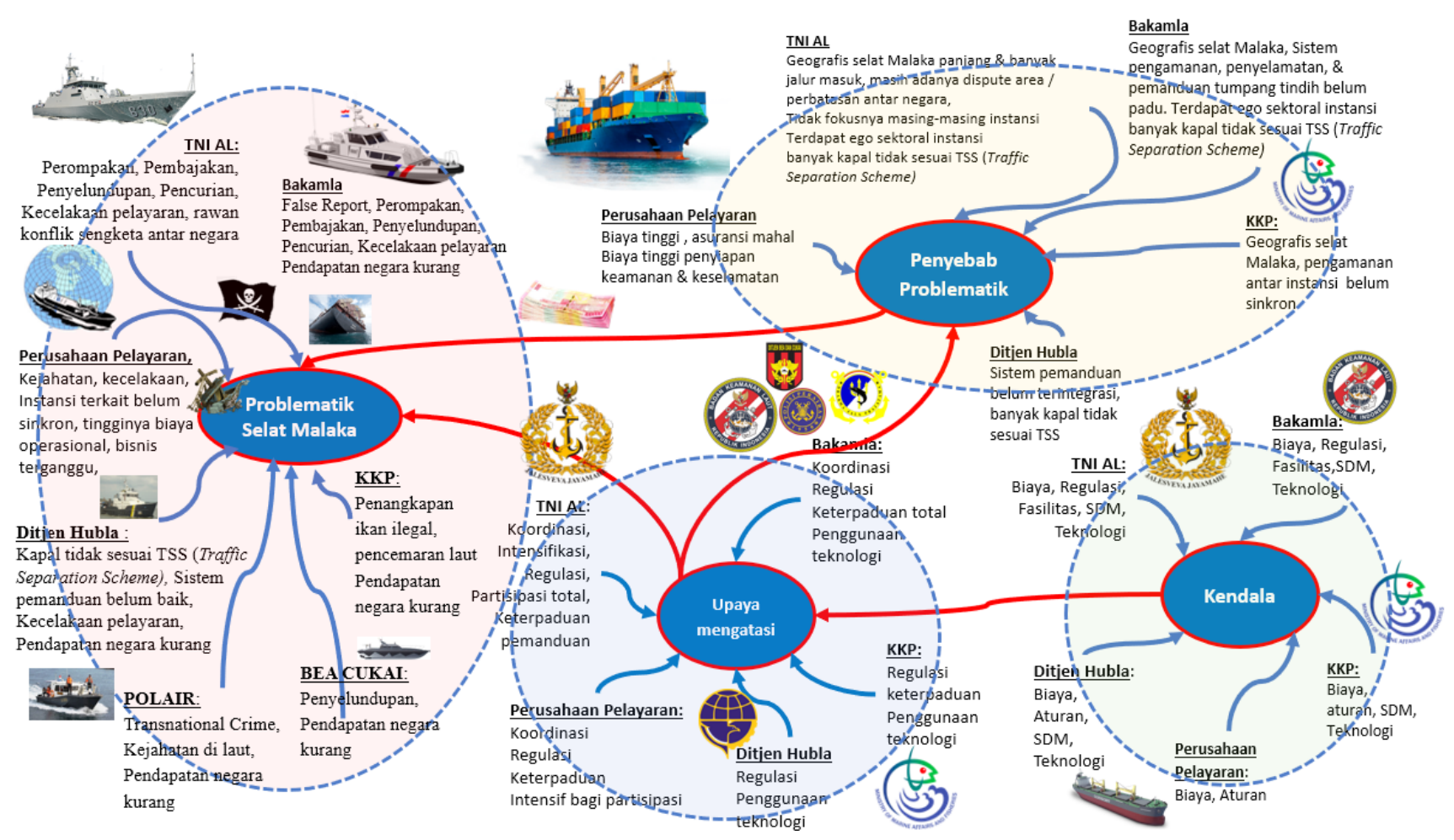

Gambar 1. Rich picture situasi problematik di Selat Malaka

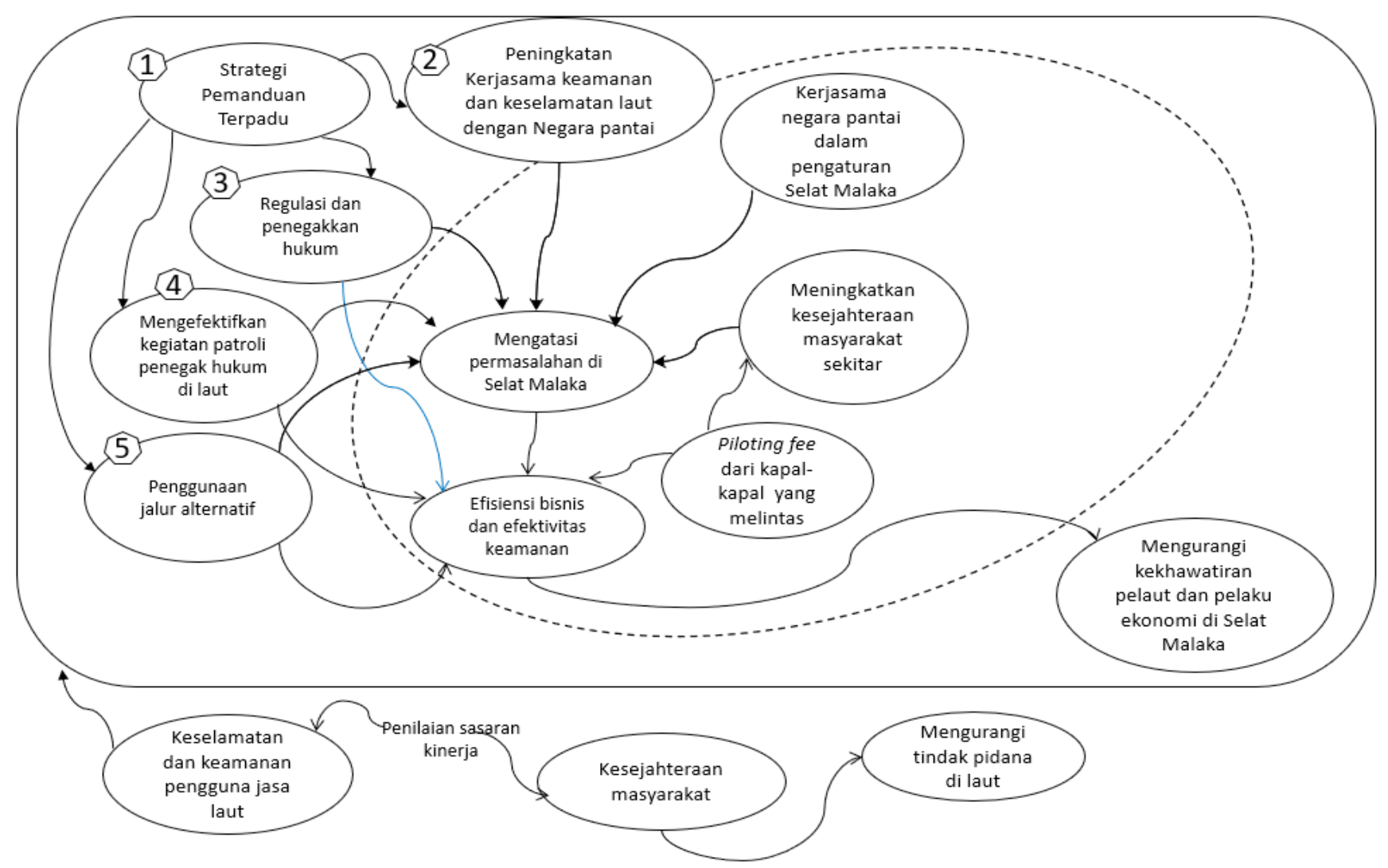

Gambar 2. Model konseptual 
Tahap keenam - Menentukan Perubahan yang Memungkinkan, Sesuai dengan yang Diharapkan (Feasible and Desirable Change)

Pada tahap ini peneliti menentukan perubahan yang memungkinkan. Berdasarkan temuan-temuan di lapangan, diperoleh fakta bahwa saat ini belum tercapai kesetimbangan antara efisiensi ekonomi dan efektifitas instansi pemerintah dalam menjaga keamanan dan keselamatan pelayaran di Selat Malaka. Untuk mencapai hal tersebut diperlukan strategi yang tepat dalam menangani sistem transportasi. Di dalam menentukan strategi yang akan diterapkan peneliti menerapkan metode yang digunakan padaJoint Military Appreciation Process (JMAP) di mana dipertimbangkan lima faktor yaitu Suitability (kesesuaian), Feasibility (kelayakan), Acceptability (penerimaan), Distinguishability (dapat dibedakan), Completeness (kelengkapan).

Strategi yang dapat dilakukan untuk menghasilkan kesetimbangan tersebut adalah dengan menerapkan Pemanduan Terpadu, yakni model penangkalan dan penindakan keselamatan dan keamanan pelayaran yang dilakukan secara komprehensif dengan memadukan Deep Sea Piloting dan personel keamanan sipil yang on board atau berada di atas kapal selama pelayaran di Selat Malaka sebagai bagian dari sistem keselamatan dan keamanan bagi pengguna jasa angkutan laut. Strategi Pemanduan Terpadu bermanfaat ganda baik untuk keselamatan navigasi maupun mencegah ancaman tindak pidana di laut, seperti perompakan dan penyeludupan. Sebagaimana yang diungkapkan oleh Bateman (2010) dimana pemberlakuan wajib pandu, sebagai bentuk pencegahan peningkatan kecelakaan kapal. Tren baru yang seharusnya diterapkan adalah perluasan navigasi baik di wilayah pesisir maupun Particularly Sensitive Sea Area (PSSA), selain pemanduan terpadu diperlukan pula PSSA sebagai konsekuensi kepedulian negara-negara pantai terhafap kesehatan pesisir dan lingkungan.

Untuk memastikan kualitas keamanan yang dihasilkan serta kelancaran koordinasi antara pihak-pihak terkait, di dalam penerapan Pemanduan Terpadu ini terdapat beberapa inisiatif yang harus dilakukan yaitu, 1) Menetapkan mekanisme permanen bersama sebagai pusat monitoring, pelaporan, pertukaran informasi intelijen, serta quick response command yang melibatkan operasi pengawasan dan juga penindakan dan pemaksaan melalui kekuatan penegak hukum negara-negara pantai 2) Memastikan pelaksanaan patroli laut secara efektif, 3) Melakukan koordinasi antar instansi di Indonesia dan antar Angkatan Laut negaranegara pantai, 4) Melakukan investigasi dan tindakan terhadap para pelaku kejahatan langsung di pusat kegiatannya (Sumatera dan pulau-pulau sekitarnya), 5) Menentang penggunaan PMSC (Private Maritime Security Company) untuk melindungi kapal-kapal yang melewati Selat Malaka, 6) Mendorong komitmen negara-negara pengguna untuk berpartisipasi dalam pengembangan kemampuan security and safety dalam penyediaan alat bantu navigasi dan membangun sistem command and control yang canggih, 7) Membentuk pusat koordinasi regional untuk melakukan koordinasi response and enforcement untuk mewujudkan tindakan nyata dari laporan dan data yang dihasilkan patroli laut.

Adapun lingkup wilayah Pemanduan Terpadu seperti dapat dilihat pada Gambar 3, meliputi: 1) Pemanduan yang melintas Selat Malaka dan Singapura $( \pm 48$ Km) dari pulau Iyu Kecil ke Pulau Nongsa Batam, 2) Pemanduan dari Utara Pelabuhan Belawan hingga area Transfer STS Tanjung Balai Karimun, 3) Pemanduan dari Utara Belawan hingga lokasi berlabuh Transit Pulau Nipah (Nipah Transit Anchorage Area - NTAA), 4) Pemanduan dari Utara Belawan hingga Pulau Nongsa Batam, 5) Pemanduan dari Utara Belawan hingga Suar Horsburgh, 6) Pemanduan dari Utara Belawan hingga Pelabuhan Kuala Tanjung, Pelabuhan Dumai dan Sungai Pakning (Bengkalis), 7) Pemanduan dari Suar Horsburgh hingga area Transfer ship-to-ship (STS) Tanjung Balai Karimun, NTAA, Pelabuhan Kuala Tanjung, Pelabuhan Dumai dan Sungai Pakning (Bengkalis), Pelabuhan Belawan, Pelabuhan Lhokseumaue.

Penerapan Pemanduan Terpadu diharapkan akan dapat mengisi kekosongan sektor patroli, mengefektifkan operasional keamanan dan mengefisienkan biaya patroli keamanan di Selat Malaka, di samping menambah pendapatan negara dari piloting charge serta memberi peluang untuk terciptanya lapangan kerja baru. Lebih dari itu, Pemanduan Terpadu ini akan mengurangi jumlah alokasi pengunaan Kapal patroli di Selat Malaka sehingga kapal patroli keamanan di laut dapat digunakan untuk patroli di sektor patroli lainnya. 


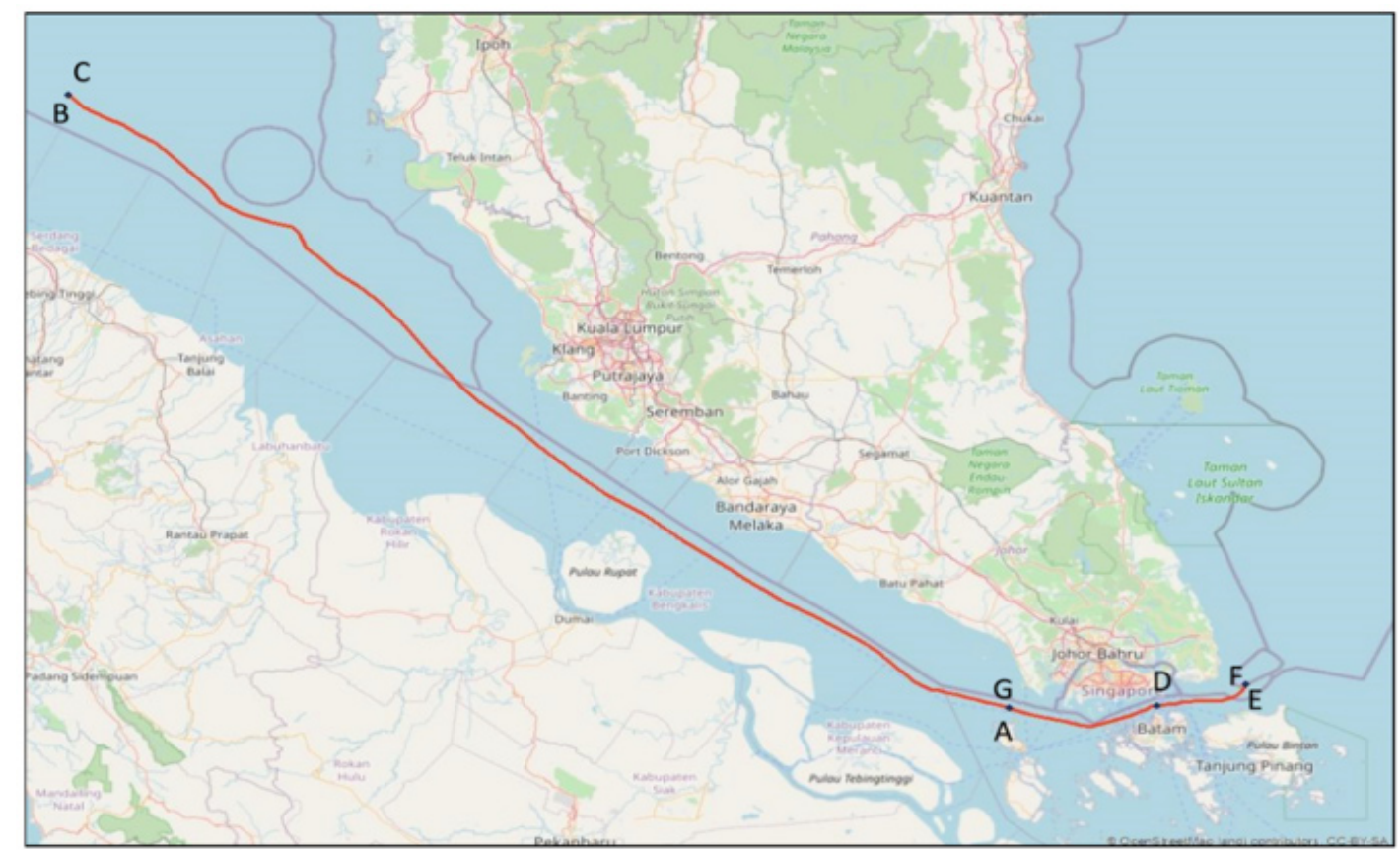

Gambar 3. Lingkup wilayah Pemanduan Terpadu

\section{Tahap ketujuh - Tindakan Perbaikan (Action to Improve the Problem Situation)}

Mengingat keterbatasan waktu, serta kompleksitas yang akan memakan waktu sangat panjang, maka sebagai pengganti dari langkah ketujuh dilaksanakan Tactical Floor Game (TFG), yaitu metode yang lazim digunakan di dunia militer untuk menguji Rencana Operasi agar dapat diketahui apakah segala tahap dalam rencana operasi tersebut telah diakomodasi dan agar diketahui kemungkinan keberhasilan dari rencana operasi tersebut. Adapun dalam penelitian ini TFG dilaksanakan untuk mengetahui tugas dan peran masingmasing pihak sehingga diharapkan akan diketahui prosedur operasi standar yang harus diterapkan pada Strategi Pemanduan Terpadu ini.

\section{Implikasi Manajerial}

Hasil penelitian ini tentunya akan memiliki dampak secara manajerial dalam penerapan strategi pemanduan terpadu untuk mencapai kesetimbangan ekonomi dan keamanan di Selat Malaka. Adapun solusi yang dapat dilakukan oleh TNI AL dan Bakamla yaitu konsep perencanaan operasi tidak lagi dilakukan secara individual, melainkan secara terkoordinasi. Dengan demikian, akan terhindar terjadinya penumpukan unsur-unsur kapal patrol di satu lokasi yang sama namun kosong di lokasi lainnya.
Pemanduan terpadu ini juga mengakibatkan adanya kolaborasi sistem operasional antara TNI AL, Bakamla dan Direktorat Perhubungan Laut Kementerian Perhubungan serta Pelindo yang akan menghasilkan Picture compilation dari situasi keamanan dan keselamatan di laut, bukan saja di sepanjang Selat Malaka namun di seluruh wilayah laut Indonesia. Hal ini menimbulkan dampak terhadap SDM yang diperlukan dan kolaborasi dari adanya strategi ini juga bertambah.

Penerapan strategi pemanduan terpadu memiliki dampak kepada teknologi yaitu adanya regulasi keterpaduan penggunaan teknologi untuk mengatasi situasi problematik yang ada. Dengan demikian prinsip interoperability harus sudah dipahami, direncanakan dan dilaksanakan oleh berbagai instansi penegak hukum di laut dalam pengembangan sarana dan prasarana khusunya peralatan elektronika.

\section{KESIMPULAN DAN SARAN}

\section{Kesimpulan}

Strategi Pemanduan Terpadu merupakan solusi yang ditawarkan untuk memecahkan permasalahan yang dihadapi oleh para pihak yang terlibat di dalam pemanfaatan transportasi laut di perairan Selat Malaka untuk mencapai win-win solution berupa kesetimbangan antara efisiensi ekonomi dan efektifitas instansi 
pemerintah dalam menjaga keamanan dan keselamatan pelayaran di Selat Malaka. Strategi Pemanduan Terpadu diharapkan akan sukses apabila terjadi penerimaan oleh semua pihak serta adanya koordinasi dan kolaborasi di antara pihak-pihak terkait. Dengan penerapan Pemanduan Terpadu, diharapkan akan dapat mengisi kekosongan sektor patroli, mengefektifkan operasional keamanan dan mengefisienkan biaya patroli keamanan di Selat Malaka, di samping menambah pendapatan negara serta memberi peluang untuk terciptanya lapangan kerja baru.

\section{Saran}

Strategi Pemanduan Terpadu diharapkan akan sukses apabila terjadi penerimaan oleh semua pihak serta adanya koordinasi dan kolaborasi di antara pihakpihak terkait. Dengan penerapan Pemanduan Terpadu, diharapkan akan dapat mengisi kekosongan sektor patroli, mengefektifkan operasional keamanan dan mengefisienkan biaya patroli keamanan di Selat Malaka, di samping menambah pendapatan negara serta memberi peluang untuk terciptanya lapangan kerja baru. Untuk memperkaya hasil penelitian, disarankan agar penelitian ini dilanjutkan dengan melakukan riset kuantitatif berupa penghitungan valuasi nilai penghematan atau efisiensi biaya yang ditimbulkan dari penerapan Strategi Pemanduan Terpadu, baik efisiensi bagi pihak pelaku bisnis sebagai pengguna jasa di laut maupun bagi pihak pemerintah sebagai penyelenggara.

\section{DAFTAR PUSTAKA}

Bateman S. 2010. Coastal state Regulation of Navigation in adjacent waters - the example of the Torres Straits and Great Barrier Reef, University of Wollonggong.

Burns GM. 2013. Estimating the Impact of Maritime Security; Financial tradeoffs between Security and Efficiency. Springers.

Burns GM. 2016. Logistics and Transportation Security: Strategic, Tactical, and Operational Guide to Resilience. CRC Press Taylor \& Francis Group.

Button K, Thibault M. 2005. The political economy of maritime container security. Agecon Search. Research in Agricultural \& Applied Economics. Issue date: 2005-3

Calamur K. 2017. High Traffic. High Risk in the Strait of Malacca. The Atlantic. Reuter.

Castonguay J. 2018. International shipping: Globalization in Crisis. https://www. visionproject.org/images/img_magazine/pdfs/ international_shipping.pdf ( 28 Mar 2020).

Checkland P, Scholes J. 1990. Soft System Methodology in action. Wiley.

Checkland P, Poulter J. 2006. Learning for Action: A Short Definitive Account of Soft Systems Methodology. and Its Use for Practitioners. Wiley.

Crawford C. 1990. The Global Dilemma: Guns or Butter. Mindscape.

Dombrowski P. 2005. Guns and Butter. The Political Economy of International Security. Lynne Rienner Publisser. Boulder London.

Dong SW. 2015. Maritime Logistics; A Guide to Contemporary Shipping and Port Management. Kogan Page.

Fargo TB. 2004. Chilly response to U.S. plan to deploy forces in the Strait of Malacca. Institute for The Analysis of Global Security.

Gunawan H. 2014. Pengantar Transportasi dan Logistik. Jakarta: PT Rajagrafindo Persada

Halpern BS. 2008. A Global Map of Human Impact on Marine Ecosystems. Reports Science.

Hanoch G. 1975. The elasticity of scale and the shape of average costs. American Economic Review, 1975, vol. 65, issue 3, $492-97$

Hardjosoekarto S. 2012. Construction of social development index as a theoretical research practice inaction research by using soft systems methodology. System Practice and Action Research 25(6):493-509. doi:10.1007/s11213012-9237-9

Hardjosoekarto S. 2013. Dual imperatives of action research: lessons from theoretical research practice to construct social development index by using soft systems methodology. Human Resource Management Research, Scientific and Academic Publishing 49-53. doi:10.5923/j. hrmr.20130301.10

Heng Z. 2017. Impacts of Kra Canal and its toll structures on tanker traffic. Maritime Policy \& Management The Flagship Journal of International Shipping and Port Research. Routledge.

Jusuf G. 2016. Laporan Prakarsa Strategis Bidang Kemaritiman dan SDA. BAPPENAS. https:// www.bappenas.go.id/files/5115/0460/0330/ Laporan_Prakarsa_Strategis_Bidang_ Kemaritiman_dan_SDA.pdf [ 25 Mar 2020]. 
Kemenko Bidang Kemaritiman Republik Indonesia. 2016. Rencana Aksi Kebijakan Kelautan Indonesia 2016 -2019. Jakarta: Kemenkomar RI.

Khalid N. 2006. Burden sharing, security and equity in the Straits of Malacca. The Asia-Pacific Journal. November 2, 2006 Vol. 4 Issue 11.

Khisty, C. J. 1995. Soft-systems methodology as learning and management tool. Journal of Urban Planning and Development. 121(3), 91-107

Mudric M. 2011. Armed guards on vessels: Insurance and liability. Poredbeno Pomorsko Pravo 50 (2011), 165, page 217 - 268

Nunez C. 2019. Our oceans are under attack by climate change. Overfishing. National Geographic published March 21, 2019. https://www. nationalgeographic.com/environment/habitats/ ocean/ [ 25 Mar 2020].

Pelindo III. 2017. Press release: Pelindo III sosialisasikan perubahan pola pandu dan tunda di perairan Gresik.

Roberts J, Tsameyi M, Workman T, Johnson L. 2005. The western European PSSA proposal: A "politically sensitive sea area". Marine Policy 29(5):431-440

Tempest M. 2012. Legal Consderation for Private Naval Company Armed Anti-Piracy Escorts. Routledge.

The International Hydrographic Organization (IHO). 2013. Limits of Oceans and Seas. https://www. marineregions.org/.[ 25 Mar 2020].

Uchiyama K. 2009. Concise Theoretical Grounding of Action Research: Based on Checkland's Soft Systems Methodology and Kimura's Phenomenological Psychiatry. Daito Bunka University, Japan. 